\title{
The Impact of Rice Milling On Poverty Reduction in the Three Geo-Political Zones of Benue State, Nigeria
}

\author{
${ }^{1}$ Okpe, Isa.J, ${ }^{2} \mathrm{Uji}$, Terese, ${ }^{3}$ Okpachu, Steve. A \\ ${ }^{1}$ Department of Economics, Benue State University, Makurdi \\ ${ }^{2}$ Department of Economics, College of Education, Oju \\ ${ }^{3}$ Department of Agricultural of Education Federal College of Education (T) Potiskum
}

\begin{abstract}
This study examined the impact of rice milling on poverty reduction in the three geo-political zones of Benue State. Data were obtained through structured questionnaires, focused group discussions and oral interviews. The study adopted a purposive sampling with the aid of Yamen's Technique and a sample size of 375 respondents was selected. The study used descriptive statistical tools, budgetary analysis and logistic regression to analyze data for this study. The study found that rice milling activity has reduced the probability of its operators been poor in Benue State, which means that rice milling activity is a poverty reducing enterprise. The study also revealed that rice milling activity in the study area was faced with several problems which include poor pricing of locally milled rice, problem of electricity, water supply, increasing cost of paddy rice, high cost of milling as a result of increase in cost of equipments and the problem of capital. The study recommended that the provision of necessary incentives such as funds to encourage unemployed youths; ensure all year round production of rice through irrigation; form cooperative societies among rice millers so that they will have easy access to loans.
\end{abstract}

Key Words: Poverty, Poverty Reduction, Rice Milling/Processing

\section{Introduction}

The issue of poverty in Nigeria is a paradox. It is a case of poverty in the midst of plenty. Despite Nigeria's natural and human resource potentials, the national poverty rate has been on the increase for more than two decades with adverse consequences on the welfare of the population. According to National Bureau of Statistics (2004), national poverty rates have increased from $28.1 \%$ in 1980 to $54.4 \%$ in 2004. Okpe and Abu observed that the level of poverty in Nigeria has been monumental over the years. Also, according to CIA (2009) World Factbook Report that in terms of human development index Nigeria ranked $158^{\text {th }}$ out of 159 countries surveyed.

The failure of successive government efforts to reduce the scourge of poverty in Nigeria through various programmes and schemes such as Operation Feed the Nation(OFN), Green Revolution, Better Life for Rural Women, National Directorate of Employment (NDE) etc in spite of the fact that these programmes and policies were aimed at poverty reduction suggests that poverty reduction is the most difficult challenge facing Nigeria, and the greatest obstacle to the pursuit of sustainable socio-economic growth; hence the need to employ measures of poverty reduction which reflects the ethnic, socio-cultural and economic peculiarities of the target group or populace.

Benue State is predominantly agrarian and it is acclaimed the food basket of the nation, and hence requires a carefully targeted agricultural approach to poverty reduction. Nigeria has the potential of becoming a great rice market and if properly tapped, there is the potential benefit of rice production and milling which may affect all the key players and stakeholders. But, little or no information exists on the opportunities of income generation and employment creation in rice milling enterprises especially as it affects the geo-political zones in Benue State.

It is in recognition of this problem that this paper examined the impact of rice milling on poverty reduction in the three geo-political zones of Benue State.

The study was undertaken to pursue the following objectives:

i. To examine the socio-economic characteristics of rice milling operators in the three geo-political zones of Benue State.

ii. To examine the impact of income generated from rice milling activities on the standard of living of rice millers in the three geo-political zones of the state.

iii. To examine the basic problems (if any) that militates against rice milling in the three geo-political zones of the state.

The hypothesis to be tested for this study is drawn in null form as:

$\mathrm{H}_{\mathrm{o}}$ : $\quad$ Rice milling has not reduced the probability of its operators being poor in the three geo-political zone of Benue State. 


\section{Conceptual Clarifications}

\subsection{Poverty}

Most economists define poverty as a situation of low income or low consumption (Obadan, 1997) while some adopt a broader definition such as being unable to meet basic material needs including participation, identity, dignity among others (Ali and Thorbecke, 2000). Specifically, the pioneers in this field of inquiry defined poverty as a situation where the income of families was insufficient to obtain the maximum necessities for the maintenance of physical efficiency (Ravallion, 1994). This definition has been refined and extended such that it forms the background for the basic needs approach to the study of poverty. It is in this context that the concept of absolute poverty emerged.

Poverty reduction refers to a situation when specific manifestations of poverty are systematically reduced resulting in short and long term conditions. Evbuomwam (1997), opined that "poverty alleviation does not simply mean short-term relief and satisfaction of basic needs, but also the development of strategies for increasing the long-term productive potential and therefore, the income of the poor in order to achieve the longterm goal". Many employment opportunities exist in the rice milling sector if there is an inclination to invest in better processing or milling technologies (Ikechukwu, 2006). Benue State is an agrarian state that produces rice among other agro-milling crops on a large scale. Virtually in all the satellite towns/villages, there is rice milling markets where rice produced is milled and marketed, thus providing a good source of income to the rice milling operators.

\subsection{Rice Milling/Processing}

Rice processing involves all the activities that make paddy rice ready for cooking (Titilola and Akande, 2003). It involves the process of soaking paddy rice in hot or cold water in a drum, followed by a rapid exposure of the soaked paddy to steam and gradual drying for at least one day. The purpose of this operation is to respond to consumer preferences while it also has a positive effect of the grain milling properties (high recovery ratio) and on its nutrition properties. In most cases, rice processing is used synonymously with the milling or milling of rice as an agro-based activity.

\section{Literature Review and Theoretical Framework}

The study of the effect of rice on poverty reduction has gained tremendous popularity in recent times; this is because of the role it has played as a staple crop consumed by a larger segment of the population both in Africa and other parts of the world. Towards this direction, various studies have been conducted in order to ascertain its impact on poverty reduction as well as sustainable development. It is based on this that this study reviewed some of these theories.

Aderigbe (1997), researched on the profitability of rice processing in Nigeria. The study found rice processing profitable although net return per month varied among respondents. In addition, the study found that the unit net returns to processing activities increased with quantity of rice processes. This suggests that millers were achieving economies of scale in their rice processing operations and therefore should increase their levels of operations since the potential of reducing the level of poverty has been recognised. West African Rice Development Association (WARM) (2003) studied the Nigerian rice economy in a competitive world. The study revealed that local rice is less competitive than imported rice due to low quality, high production and milling cost. Studies conducted by Saito, Linquist, Keobualapha, Phanthaboon, Shirwaiwa and Horie (2006) using simple regression analyses to investigate the efficacy of upland rice cropping found that rainfall during the reproductive stage explained 38-67 percent of the variation of upland rice yield in the Philippines. In developing a framework for food security in Nigeria, Oriole (2006) observed that the framework for food security and poverty reduction should go beyond crop production and that it should centre on the political will of the government. The attention to agricultural production should go beyond providing lip services to agricultural production most especially as it affects irrigation in the economy. The effect of government policy on rice production was also done in Vietnam. Tran and Kajisa (2006) used long term regional yield and modern variety adaptation statistics as well as household data from 1996 and 2003 to investigate the effect of the Green Revolution on rice production in Vietnam. The study shows that with the end of the Green revolution in the mid 1980s in the Philippines, it is still sustained in Vietnam and the growth rate outweighs any other Asian country.

Akande (2008), researched on Nigerian rice economy. He found that Nigeria is the highest producer of rice in West Africa but is also a massive importer of rice which tends to negatively affect the price of locally produced rice. Apata, Igbalajabi and Awoniyi (2010) carried out a research on the determinant of rural poverty in Nigeria. The study acknowledged the fact that small farmers are one of the more disadvantaged and vulnerable groups in Nigeria. A similar study conducted by Akighir, Ngustav and Asom (2011) using descriptive statistics, foster, Green and Thornbeck (FGT) index and logistic regression shows that the participation of people in rice milling has the potential of reducing the level of poverty in Kwande local government area of Benue state. Their study is significant because it has bearing with this study due to the fact 
that it is from the same geographical zone with this study. Similar studies were conducted by Wiredu, Gyasi, Marfo, Asuming-Brempong, Haleegoah, Asuming-Boakye and Nsiah (2010) The study applied the average treatment effect method as well as the ordinary least squares method on 489 randomly rice selected farmers in Ghana and the result from the study shows that Gender was a major determinant of yield among farmers in the area since more yields are derived from the farm when it is male dominated. Age was also considered an important factor since experience in rice production implies accumulated knowledge in rice production. Another factor that affects rice yield by farmers is the expectation of rice farmers. It was found that expectation of rice farmers on previous harvest has significant effect on actual yield by farmers.

Accordingly, Okpe, Abur and Ominyi (2012) investigated resource use efficiency and rice production in Guma local government area of Benue state which shows that small and large farms exhibited increasing return to scale while middle scale farms demonstrated decreasing return to scale. Dinye and Ayitio (2013) carried out a study in Kassena Nankana District of Northern Ghana using treatment and control experimental approach. The study discovered that investment in irrigation infrastructure constitute an important poverty reduction strategy since it can boost agricultural production by reducing the risk associated with rainfall variability. The study also observed that modest gain has been towards poverty reduction through irrigation.

A study on the access to credit in rice production was undertaken by Akinbode (2013). The study was analysed using descriptive statistics t-test, logit regression, ordinary least squares regression and the chow test. A total of 208 rice farmers where sampled and the result shows that farmers that have access to financial credit recorded more yield and higher return which has helped to sustain the rice enterprise. The result from the logit regression shows that age, education, gender and contact with extension services significantly affect the likelihood of rice farmers' access, financial credit from micro finance banks and cooperative societies to increase rice production.

Two theories have been adopted for the purpose of this study, the vicious circle of poverty, the unbalanced growth theory, and the basic needs approach.

The vicious circle of poverty presupposes that poverty is a serious human problem that is self-perpetuating which if not properly handled can become inter generational as well as capable of affecting prosperity of another person. Nevertheless, Benue State is no exception, hence the need to address this intractable problem with all purpose of sincerity.

For Benue State whose development depends on agriculture because of the enormity of agricultural resources and the overwhelming participation of a larger proportion of Benue people in agricultural activities, any result oriented poverty alleviation programme ought to be agricultural based so that development will be communicated to the other sectors of the Benue economy.

The basic needs theory now provides the basis for a quality of life that is acceptable as non-poor; hence, the need for economic activity that can provide the means of overcoming the helplessness and misery arising from the shackles of poverty. Therefore, rice milling as an economic activity has the potentials of reducing poverty through provision of employment opportunities and income generation as sustenance.

In line with the above explanations, this paper used the above theoretical underpinning to augment the income of participants in rice milling industry breaking out of the vicious circle of poverty thereby reducing poverty in the three geo-political zones that make up Benue as a State.

\section{Materials and Methods}

The data for the study were obtained through a structured questionnaire, oral interview, personal observations as well as focused group discussions. The data resulting from the study were both quantitative and qualitative and as such, need processing and analysis. The study covers only the rice milling operators in Katsina-Ala, Makurdi and Otukpo which represent Zones, A, B and C respectively. Their records as of the time of this study shows that there are 493 parboilers, 402 winnowers, 154 engine owners, 201 sewers and porters. Therefore, the total population is collectively put at 1250 .

$$
\text { The scientific method of Yemen Taro (1967) in the form } n=\frac{N}{1+N(e)^{2}} \text { using } 95 \text { percent confidence }
$$

level was adopted in selecting the sample size of 375 respondents who are the rice millers.

Consequently, multi-variable logit regression as well as gross margin analysis was carried out in order to establish the relationship between various variables.

\section{Logit Model}

In a logit model, the endogenous variable is a dummy variable which is dichotomous with 1 representing the household if it is poor and 0 if the household is not poor (Imran, Shahnawaz and Abo, 2006). The logit as used in this study is applied to examine the impact of rice milling activity on the socio-economic characteristics of rice millers. 
The parameters were estimated by maximum likelihood within the likelihood function assuming independence over the observations.

We have:

$$
P(Y)=\frac{e}{1+e}
$$

Given that $\mathrm{Y}$ measures poverty, then $\mathrm{Y}$ might be poor (i.e. 1) or non-poor (i.e. 0). Now, taking logs and simplifying equation 3.1 , we have the likelihood simplified as:

$$
\text { LnYi }=\frac{P_{i}}{1-P_{i}}=\beta_{0}+\sum_{i=1} \beta_{K} \times K_{k i}+\mu_{i}
$$

Where:

$L n Y i=$ National log of Y (poverty status)

$X_{k i}=$ A set of household socio-economic characteristics

$\beta_{\mathrm{k}}=$ Parameters

$\mu_{\mathrm{i}}=$ Random disturbance term or error term.

The model for this study in line with the specified model is explicitly stated to include all the dependent variables as:

$$
\mathrm{DV}=\mathrm{f}\left(\mathrm{x}_{1}, \mathrm{x}_{2}, \mathrm{x}_{3}, \mathrm{x}_{4}, \mathrm{x}_{5}, \mathrm{x}_{6}, \mathrm{x}_{7}\right)
$$

Where, DV = dependent variable (Poverty Status), calculated as:

$$
D V=\frac{\text { Average annual income of a household from rice milling activity }}{\text { Total number of days in a year }(365)}
$$

If it is less than $1 \frac{1}{2}$ dollar, it means the household is poor in which case we assign (0). If it is $1 \frac{1}{2}$ dollar and above, it means the household is non-poor, in which case we assign (1).

$\mathrm{x}_{1}=$ Annual income from rice milling; $\mathrm{x}_{2}=$ Quantity of rice milled; $\mathrm{x}_{3}=$ Quantity of food consumed (1 if 3 times a day, 0 if otherwise); $x_{4}=$ Quality of house lived in (1 if zinc roof and cemented walls/floors, 0 if otherwise); $\mathrm{x}_{5}=$ Access to medical services ( 1 if there are visits to specialize and/or general hospitals, 0 if otherwise); $x_{6}=$ Access to clothing ( 1 if new cloth is purchased in a year, 0 if otherwise $) ; x_{7}=$ Family members education ( 1 if have access to formal education, 0 if otherwise).

Therefore, re-writing the dependent function to form the specific model for this study, we have:

$$
\mathrm{DV}=\beta_{0}+\beta_{1} X_{1}+\beta_{2} X_{2}+\beta_{3} X_{3}+\beta_{4} X_{4}+\beta_{5} X_{5}+\beta_{6} X_{6}+\beta_{7} X_{7}+\mu \quad \ldots
$$

Head count ratio was used to measure poverty status as:

$$
H=\frac{Q}{N}
$$

Where:

$\mathrm{H}=$ Head count ratio; $\mathrm{Q}=$ Number of household below poverty line; $\mathrm{N}=$ Total number of households in the population

\subsection{Budgetary Analysis}

Budgetary analysis was carried out to determine the profitability of rice milling in the three geopolitical zones. The gross margin was estimated as the difference between total revenue and total variable cost in rice milling operations as stated in equation 3.6 below:

$$
\pi=\mathrm{P}_{\mathrm{i}} \mathrm{Q}_{\mathrm{i}}-\mathrm{TC}_{\mathrm{i}}
$$

Where: $\pi=$ Gross Margin $(\mathrm{N}) ; \mathrm{P}_{\mathrm{i}}=$ Price; $\mathrm{Q}_{\mathrm{i}}=$ Output of individuals in rice milling; $\mathrm{TC}_{\mathrm{i}}=$ Total cost of production.

The use of ratio was computed to assess the performance of the rice milling operation during the survey period.

A priori expectation for this study shows that, the variables, which are the $\mathrm{x}$ 's are expected to be negatively signed since the x's have inverse relationship with $\mathrm{P}(\mathrm{Y})$. This is because increase participation will increase profit and as a result improves the standard of living in absolute poverty status of those rice millers.

The decision rule for the hypothesis is: We reject the null hypothesis to accept the alternative hypothesis if the estimated function showing the likelihood ratio statistic value is greater than its poverty value. 


\section{Presentation of Results}

This section of the paper examines the results of the study and the discussions pertaining to them and the findings from the results.

In order to ascertain the impact of rice milling on the poverty status of the sampled respondents, the logistic regression model specified in this paper was estimated using the maximum likelihood estimation technique. The logistic regression results were collected and presented in Table 1.

Table 1: Results of the Logistic Regression Model

\begin{tabular}{|l|l|l|l|l|l|}
\hline Variables & Coefficients & S.E & Wald Test & Sig & Exp $(\beta)$ \\
\hline ANI $\left(\mathrm{x}_{1}\right)$ & -0.688 & 0.000 & 0.050 & $0.038^{* *}$ & 0.578 \\
QTYRM $\left(\mathrm{x}_{2}\right)$ & $-0 / 927$ & 0.005 & 0.006 & $0.029 * *$ & 0.390 \\
QTYFC $\left(\mathrm{x}_{3}\right)$ & -0.254 & 6.778 & 0.000 & $0.036^{* *}$ & 0.120 \\
QLTYHL $\left(\mathrm{x}_{4}\right)$ & -0.990 & 0.528 & 57.191 & $0.060^{*}$ & 0.185 \\
ACCMS $\left(\mathrm{x}_{5}\right)$ & -0.407 & 1.849 & 0.000 & $0.052^{*}$ & 0.629 \\
ACCLTA $\left(\mathrm{x}_{6}\right)$ & 0.951 & 4.633 & 0.000 & $0.240 *$ & 0.254 \\
FAMEDU $\left(\mathrm{x}_{7}\right)$ & -0.167 & 6.289 & 0.000 & 0.013 & 0.140 \\
Constant & 43.972 & 8.166 & 0.000 & 0.996 & 1.250 \\
\hline
\end{tabular}

Source: SSPS Output, 2013

Nagelkerke R Square is 0.541, Log likelihood is 101.592a, chi-square is 295.047.

$* * *$ significant at $1 \%$, ** significant at $5 \%$, * significant at $10 \%$

Omnibus Tests of Model Coefficient give us a chi-square (Likelihood Ratio, LR). The chi-square of 295.047 on $7 \mathrm{df}$ is significant beyond 0.001 . This indicates that the overall model is statistically significant and has performed very well. In other words, the model predicts with the high degree of accuracy, the likelihood of a sampled respondent being poor or non-poor in the study area.

The results from Table 1 shows that the coefficient on ANI variable (i.e. Annual income from rice milling) is negative (-0.688) which is correctly signed and statistically significant at $5 \%$ level of significance. This implies that average annual income has influence on the probability of a sampled respondents being nonpoor (note that the objective is to see a respondent poverty status change from poor to non-poor as a result of involvement in rice milling enterprise). Also, the $\operatorname{Exp}(\beta)$ of 0.578 indicates that a unit change (increase) in annual income of the sampled respondents from rice milling activity reduced their likelihood of being poor by $57.8 \%$.

Table 1 further shows that the coefficient on the QTYRM variable (i.e. quantity of rice milled) is also negative (-0.927) which is correctly signed and statistically significant at $5 \%$ level. This implies that the quantity of rice milled has influence on the probability of a respondent being non-poor. The $\operatorname{Exp}(\beta)$ of 0.390 shows that the odds or probability of a sampled respondents being non-poor can be explained by $39 \%$ with a unit increase in the quantity of rice milled.

The parameter estimate for the number of times a rice milling operator and his household feeds in a day (QTYFC) with income generated from the rice milling enterprise is negatively and correctly signed $(-0.254)$ and statistically significant at 5\% level. This implies that the number of times a rice miller and his household feed in a day have influence on the probability of a respondent being non-poor. The $\operatorname{Exp}(\beta)$ of 0.120 indicates that the probability of a sampled respondent being non-poor can be explained by $12 \%$ with a unit increase in the number of times his or her household feeds in a day.

The parameter estimate of QLTYHL (i.e. Quality of House Lived in) that a sampled respondent sleeps is as a result of income generated from rice milling enterprise. This is negatively and correctly signed $(-0.090)$ and statistically significant at $10 \%$ level. This implies that the quality of house, the sampled respondent sleeps in has influence on the probability of him or her being non-poor. The Exp $(\beta)$ of 0.185 indicates that the probability of a sampled respondents being non-poor can be explained by $18.5 \%$ with the quality of house he or she sleeps in due to income obtained from rice milling enterprise.

The parameter estimate of ACCMS (i.e. Access to Medical Services) of the sampled respondents is negatively-correctly signed (-0.407) and statistically significant at $10 \%$ level. This suggests that access to medical services has influence on the probability of the sampled respondent being non-poor. This is because the rice milling operator would use income generated from rice milling activity to patronize a better medical service as the case may be. The $\operatorname{Exp}(\beta)$ of 0.629 shows that the probability of a sampled respondent being non-poor can be explained by $62.9 \%$ with access to medical services due to income generated from the activity of rice milling.

The coefficient of ACCLTH (access to clothing) of a sampled respondent is positively and incorrectly signed (0.9511) but it is statistically significant at $5 \%$ level. This implies that the number of times a sampled respondent buys new cloths in a year is not necessarily a function of income generated from rice milling 
enterprise. The $\operatorname{Exp}(\beta)$ of 0.254 indicated that the probability of a sampled respondent being non-poor can not be necessarily explained by $25.4 \%$ with access to clothing based on income generated from rice milling activity.

Finally, the parameter estimate of FAMEDU (i.e. Family Members' Education) is negatively-correctly signed and statistically significant at $1 \%$ level. This implies that a sample respondent's level of education as well as the number of persons he or she is training in school at various levels has influence on the probability of him or her being non-poor. The $\operatorname{Exp}(\beta)$ of 0.140 indicates that the probability of sampled respondents being non-poor is explained by $14 \%$ with the number of persons they are training in school at various levels as a result of income generated from rice milling enterprise.

Considering the fact that Omnibus Tests of model coefficients signifying the likelihood ratio is 295.047 and the Nagelkerke R square is 0.541 . We therefore, reject the null hypothesis which states that "rice milling has not reduced the probability of its operators being poor in Benue State" and conclude that rice milling has significant impact on poverty reduction in the three geo-political zones that make up Benue State. This suggests that rice milling activity contributed to poverty reduction due to income generated from the rice milling enterprise to augment an acceptable quality of life that is considered as non-poor.

Also, gross margin was calculated and summarized in Table 2 , in which rice milling activity in the study areas (Katsina-Ala, Makurdi and Otukpo) were relatively profitable. This is presented in Table 2 below.

Table 2: Profitability Measure of Rice milling in the Study Areas

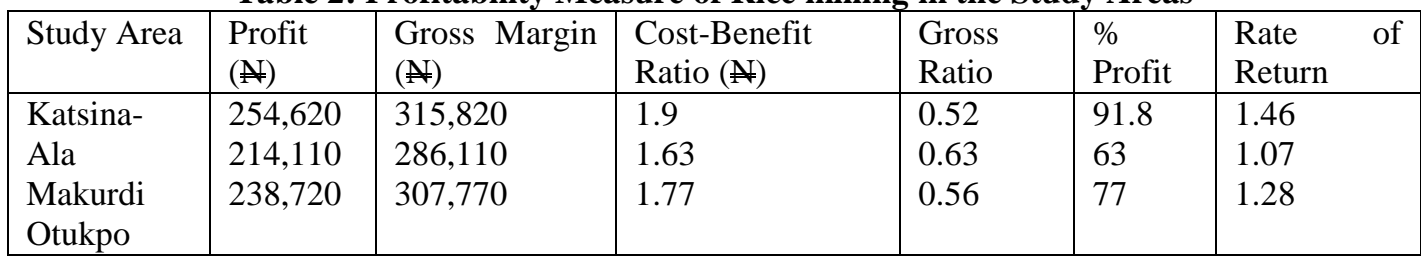

Source: Authors Summary of Computation from Field Work

The presentation in Table 2 shows that the average profit of $\$ 254,620$ for a respondent and a percentage profit of $91.8 \%$ shows that rice milling activities were profitable in Katsina-Ala rice milling area. The cost-benefit ratio indicated that a rice milling operator that invests $\$ 1$ would realize $\$ 1.91$ which implies that the rice miller in Katsina-Ala would gain $¥ 0.91$ on each $\$ 1$ expended.

The average total profit of $\$ 214,110$ for a respondent and percentage profit of $63 \%$ indicated that rice milling activity were highly profitable in Makurdi rice milling area. The cost-benefit ratio shows that a rice milling operator that invests $\$ 1$ would realize $\$ 1.63$, which implies that the rice miller would gain $¥ 0.63$ on each $\$ 1$ expended in the rice milling activity.

Table 2 also reveals that the average profit of $\$ 238,720$ for a typical sampled respondent and percentage profit of $77.1 \%$ suggest that rice milling activity is profitable in Otukpo rice milling area. The costbenefit ratio implied that a rice milling operator would gain $\$ 0.77$ on each $\$ 1$ invested in the rice milling enterprise in Otukpo rice milling area.

In spite of the contributions of rice milling to poverty reduction in the study areas, as analyzed above, the sampled respondents are still faced with constraints as presented in Table 3.

Table 3: Distribution of sampled respondents by their constraints in rice milling enterprise in Benue State

\begin{tabular}{|l|l|l|l|}
\hline S/N & Problems militating against rice milling in Benue State & Frequency & Percentage (\%) \\
\hline 1 & Poor pricing of locally milled rice & 311 & 184 \\
2 & Problem of electricity & 232 & 13.7 \\
3 & Problem of water supply & 294 & 17.4 \\
4 & Increasing cost of production & 301 & 17.8 \\
5 & High cost of milling as a result of increased cost of equipment & 263 & 15.6 \\
6 & The problem of capital & 288 & 17.1 \\
\hline & Total & $1,689^{*}$ & 100 \\
\hline
\end{tabular}

*A respondent was allowed to give more than one problem*

Source: Field Survey, 2013.

Table 3 shows the various problems affecting rice milling enterprise as indicated by individual rice milling operators.

\subsection{Discussion of Findings}

This study came up with important findings which conform to empirical literature. It was found that the income generated from rice milling activity were able to acquire them better means of transportation, good housing, clothing, food, better medical services as well as sponsor their children/wards in various schools and at 
various levels. This study conforms to studies undertaken by Akighir, Ngustav and Asom (2011) and Dinye and Ayitio (2013) that rice milling/production have the tendency of reducing poverty.

Accessing the level of profitability of rice processing this study shows that rice production is profitable in the three geo-political zones. According to results from the budgetary analysis revealed that rice milling enterprise is economically viable in Benue State and this conforms to previous studies conducted by Akighir, Ngustav and Asom (2011) and Aderigbe (1997) which observed that net return per month varied among respondents.

\section{Conclusion and Recommendations}

The null hypothesis has been rejected and the alternative hypothesis has been accepted. It was found that rice milling activity has reduced the probability of its operators being poor in Benue State. Generally, therefore, in Benue State, the study discovered that rice milling activity is poverty reducing enterprise.

Nevertheless, it was found that the enterprise is still beset with problems. Thus, we have the following recommendations:

i. Efforts should be made to provide all necessary incentives that will encourage more unemployed youths to engage in the business as a source of livelihood.

ii. The problem of low pricing of locally milled rice can be tackled through the protection of excessive importation of milled rice.

iii. All-year round production of rice should be encouraged through the introduction of irrigation practices to help curtail the problem of shortage of paddy rice.

iv. The problem of raising capital can be solved if the rice milling operators are able to form cooperative societies to enable them access loans.

v. Government should provide rice milling centres in Benue State with modern technologies especially in the key production or milling zones to help increase the quantity and quality of rice milled.

\section{References}

[1]. Adesonye, A. O., S. A. Yusuf and D. O. Awotide (2008). Assessment of Poverty among Urban Farmers in Ibadan Metropolis, Nigeria Journal of Humanities, Ibadan, Nigeria, 24(3), 201-207.

[2]. Akande(2008) An Over View of Nigerian Rice Economy. www.unep.ch/etu/etp/events/agriculture/Nigeria.pdf

[3]. Akande, S. O. and G. Akpokodje (2003). Rice Prices and Market Integration in Selected Areas in Nigeria. Agriculture and Rural Development Department Research Report.

[4]. Akighir, D. (2011). "Processing and Marketing of Rice and Poverty Reduction in Kwande Local Government Area of Benue State". An Unpublished Dissertation submitted to the Department of Economics, Benue State University, Makurdi.

[5]. Akinbode, S.O (2013) Access to Credit: Implication for Sustainable Rice Production in Nigeria. Journal of Sustainable Development in AfricaVol15 No.1`Pp 13-30

[6]. Ali, A. A. and Thorbecke (2000). The State and Path of Poverty in Sub-Saharan African: Some Preliminary Results. Journal of African Economics, a (supplement 1): $9-40$.

[7]. Apata, T. G., O. M. Apata, O. A. Igbalajobi and S.M. O. Awoniyi (2010). Determinants of Rural

[8]. Poverty in Nigeria: Evidence from Small Holder Farmers in South-Western Nigeria. Journal of Science and Technology Educational Research, Vol. 1 (4), pp 85-91

[9]. Central Bank of Nigeria (2003). Statistical Bulletin (CBN) Abuja, Nigeria.

[10]. CIA (2009) The World FactBook Washington DC

[11]. Dinye, R.D and J.Ayitio (2013) Irrigated Agriculture Production and Poverty Reduction in Northern Ghana: A Case Study of the Tono Irrigation Scheme in Kassena Nankana District. Internal Journal of water Resources and Environmental Engineering Vol. 5(2) Pp 119-133, February

[12]. Evbuomwan, G. O. (1997). Poverty as a Social Issue: A Theoretical Note in Nigerian Poverty. Teriba (ed) The Nigerian Economic Society, Ibadan.

[13]. Ikechukwu, A. and K. M. Omotola (2006). Rice Milling in Nigeria. Unpublished Student Researchers on Department of Agricultural Production in Sub-Saharan African.

[14]. Imram, H.O . A, Shahnawaz and J. Agbo(2006) Probabilistic Logistic Regressionwww.gogle.com.ng/search?.q=Imran,+Shahnawaz+and+Agbo(2006)+onlogic+regression

[15]. National Bureau of Statistics (2004). Poverty Profile for Nigeria.

[16]. National Bureau of Statistics (2008). Poverty Profile for Nigeria.

[17]. National Planning Commission (2004). National Economic Empowerment and Development Strategy (NEEDS) Document, b3 Communications Limited, Lagos.

[18]. Obadan, M. (1997). "Analytical Framework for Poverty Reduction: Issues of Economic Growth Versus other Strategies in Poverty Alleviation in Nigeria. A selected paper for the $1997 \quad$ Annual Conference of the Nigeria Economic Society, 1997.

[19]. Okpe, I.J. C. Abur and. O. Ominyi (2012) Resource use efficiency and Rice Production in GumaLocal Government Area of Benue State: An Application of stochastic Production Function . International Review of Social Sciences and Humanities Vol 3 No.1 Pp 10116.

[20]. Okpe. I.J and G. A Abu (2009) Foreign Direct Investment and Poverty Reduction inNigeria(1975-2003). Journal of Social Science Vol 19 No. 3 Pp 205-211

[21]. Oriola, E.O (2009) A Framework for Food Security and Poverty Reduction in Nigeria. EuropeanJournal of Social Sciences- Vol8 No.1

[22]. Ravallion, M. (1994). Poverty Comparisons. Harwood Academic Publishers Chur, Switzerland.

[23]. Saito, K. B. Linguist. B. Keobualapha. K. Phanthaboon. T. Shiraiwa and T. Horie (2006) Cropping Intensity and Rainfall Effects on Upland Rice Yield in Northern Laos. Plant Soil Pp 175-185 
[24]. Titilola, G. and S. O. Akande (2003). The Nigerian Rice Economy in a Competitive World. Constraints, Opportunities and Strategies Choices. Rice Processing in Nigeria.

[25]. Tran, T. U and K. Kajisa (2006) The Imapct of Green Revolution on Rice Production in Vietnam. The Developing Economies, XLIV-2 June Pp 167-89

[26]. Wiredu, A.N, K.O Gyasi, K. A Marfo, S. Asuming-Brempong, J. Haleeegoah, A. Asuming Boakye and B.F. Nslah (2010) Impact of Improved Variety on YIELD OF Rice Producing Households in Ghana. Second Africa Rice Congress, Bamako, Mali Pp 22-26 March. Innovation and Partnership to Realize Africa's Rice Potential Pp 3.6.1-3.6.5

[27]. Yemen Taro (1967) Statistics: An Introductory Analysis, $2^{\text {nd }}$ Edition, New York: Harper and Row Zeigler, R.S (2006) Rice Research for Poverty Alleviation and Environmental Sustainability inAsia. www.niaes.affre.go.jp/sinfo/sympo/hi8/20061212pdf/s3_zeigler.pdf 